\title{
SURVIVAL OF NONAGENARIAN PATIENTS WITH HIP FRACTURES: A COHORT STUDY
}

\author{
SOBREVIDA DE PACIENTES NONAGENÁRIOS COM \\ FRATURAS DE QUADRIL: ESTUDO DE COORTE
}

\author{
Alexa Ovidiu ${ }^{1}$, Gheorghevici Teodor Stefan ${ }^{1}$, Popescu Dragos ${ }^{1}, V_{\text {eliceasa } \text { Bogdan }^{1} \text {, Alexa loana Dana }}^{2}$ \\ 1. Grigore T. Popa University of Medicine and Pharmacy, Department of Orthopedics and Traumatology, lasi, Romania. \\ 2. Grigore T. Popa University of Medicine and Pharmacy, Geriatrics Department, lasi, Romania.
}

\section{ABSTRACT}

Objective: The objective of this study was to assess survival and factors that may influence survival in nonagenarians with hip fracture. Methods: We retrospectively analyzed 134 nonagenarian patients admitted for hip fractures over a period of 9 years, and reviewed medical records and survival data from the National Population Register. The analysis included demographic data, ASA score, surgical delay, type of treatment, and mortality. Results: Mean patient age was 92.53 years (range 90-103 years). Of the total, $35.8 \%$ of the fractures involved the femoral neck and $64.2 \%$ were in the trochanteric region. Overall mortality was $18.7 \%$ at 30 days, and $9 \%$ at one year. Mean survival for the entire sample was $683 \pm 78.1$ days, with a median of 339 days; survival in men and women was $595 \pm 136.8$ days and $734 \pm 94.6$ days, respectively. We found that type of fracture $(p=0.026)$ and ASA score $(p=0.004)$ were the main factors influencing survival. Kaplan-Meier survival analysis indicated that patients with extracapsular fractures treated by internal fixation had a better survival rate $(p=0.047)$. There was no significant differences between sexes $(p=0.102)$ or diagnosis $(p=0.537)$. Conclusion: Although nonagenarian patients have numerous comorbidities, surgical treatment using internal fixation seems superior to a conservative approach. Level of Evidence III, Retrospective Comparative Study.

Keywords: Hip fractures. Femoral neck fractures. Aged, 80 and over. Survival analysis.

\section{RESUMO}

Objetivo: O objetivo deste estudo foi avaliar os fatores que podem influenciar a sobrevida de nonagenários com fratura do quadril. Métodos: Foram analisados retrospectivamente 134 pacientes nonagenários internados por fraturas de quadril e seus prontuários, em um período de nove anos. Efetuou-se a revisão de prontuários médicos e os dados sobre a taxa de sobrevida do Registro Nacional de População. A análise incluiu dados demográficos, classificação ASA, atrasos na cirurgia, tipo de tratamento e mortalidade. Resultados: A média de idade dos pacientes foi 92,53 anos (de 90 a 103 anos). Do total, 35,8\% das fraturas localizaram-se no colo do fêmur e 64,2\% na região trocantérica. A mortalidade geral foi 18,7\% aos 30 dias seguintes e 9\% em um ano. A média de sobrevida de toda a amostra foi de $683 \pm 78,1$ dias, com mediana de 339 dias. A sobrevida em homens e mulheres foi, respectivamente, $595 \pm 136,8$ dias e $734 \pm 94,6$ dias. Constatamos que o tipo de fratura $(p=0,026)$ e a classificação ASA $(p=0,004)$ foram os principais fatores que influenciaram a sobrevida. A análise de sobrevida pelo método Kaplan- Meier indicou que os pacientes com fraturas extracapsulares tratados com fixação interna tiveram taxa de sobrevida melhor ( $p=0,047)$. Não houve diferença significativa entre sexos ( $p=0,102)$ ou no diagnóstico $(p=0,537)$. Conclusão: Apesar das numerosas comorbidades em pacientes nonagenários, o tratamento cirúrgico com fixação interna parece ser superior à abordagem conservadora. Nível de Evidência III, Estudo Retrospectivo Comparativo.

Descritores: Fraturas do quadril. Fraturas do colo femoral. Idoso de 80 anos ou mais. Análise de sobrevida.

Citation: Ovidiu A, Stefan GT, Dragos P, Bogdan V, Dana Al. Survival of nonagenarian patients with hip fractures: a cohort study. Acta Ortop Bras. [online]. 2017;25(4):132-6. Available from URL: http://www.scielo.br/aob.

\section{INTRODUCTION}

Hip fractures represent a major public health problem because of their substantial impact on health and healthcare costs. It is estimated that approximately 6.5 million hip fractures will occur around the world in 2050 . The majority of hip fractures (80\%) occur in persons aged 65 years and older. ${ }^{1,2}$
Recent demographic data confirm that industrialized countries are experiencing longer life expectancies and that the fastest-evolving population segment is people aged 90 and older. Considering that $35 \%$ of people over age 65 will suffer at least one trauma from same-level falls, it is clear why hip fracture among the elderly is the most frequent cause of hospitalization associated with severe disability. ${ }^{3}$ 
The traumatic pathology of hip fracture prevails in women; the main cause is osteoporosis, and the proximal femur is one of the main areas affected. In the 1970s, specialized journals indicated that $2 \%$ of women over age 85 fracture a hip each year, while the percentage for males is around $0.6 \% .{ }^{4}$ The risk of hip fracture among people above age 85 is 10 to 15 times higher than in the population between 60 and 65 years old. Increased life expectancy means that women are now more likely to fracture a hip than develop breast cancer. ${ }^{5}$ Over $90 \%$ of hip fractures in elderly patients result from low-energy trauma, namely same-level falls, and most of these fractures occur in the home. In comparison with other patients, the elderly are more exposed to this kind of trauma at night because they often use diuretics or medications that include benzodiazepines. ${ }^{6,7}$

The age of patients with hip fracture is known to be associated with a significant increase in postoperative complications, high immediate and long-term mortality, and poor functional prognosis. The maximum vulnerability is specific to the first 3-6 months, and death in the first 12 months must be perceived as an effect of trauma or surgical intervention. If post-fracture status involves limits on activity, this must be considered a component of long-term mortality because it favors the intensification of comorbidities. ${ }^{8}$ Our retrospective study analyzed patients older than 90 years who fractured a hip in order to evaluate if the patient survival period is influenced by operative treatment. We hypothesized that surgical treatment provided better survival rates in the nonagenarian population with hip fractures.

\section{MATERIAL AND METHODS}

This retrospective study assessed all nonagenarian patients admitted to our university hospital between 1 January 2007 and 31 December 2015 according to demographic data (gender, age, background) and medical information (intra- or extracapsular fracture type, surgical or non-surgical treatment, type of surgical intervention [internal fixation or arthroplasty], ASA score, status at hospital discharge). We only considered those comorbidities which were described as significant to the prognosis of patients with hip fracture according to Aharonoff et al. ${ }^{9}$

We also collected data about the time between the occurrence of the fracture and the date of surgery, hospitalization period, and complications and deaths during hospitalization.

The data were obtained through the Hospital Manager Program, hospital charts, and surgical protocols.

The inclusion criteria were: single level I trauma center, age $>90$ years, patients with intracapsular and extracapsular fractures (ICD10-AM codes S72.0 and S72.1), and unintentional fall (ICD-10-AM codes W00 to W19).

The exclusion criteria were: open fracture, subtrochanteric fracture, polytrauma, pathological fracture, and patients transferred to other hospitals (3 cases, at the patient's request).

Because the program does not provide information about the date the hip fracture occurred, the hospital admission date was considered as the date the fracture occurred, since hip fracture leads to total functional incapacity and patients are normally brought to the hospital by ambulance that same day. Many authors ${ }^{10,11}$ correlate the date of admission into hospital with the date of hip fracture.

After approval was obtained from the institutional review board (1/13.01.2016; no formal written approval was required, because of the retrospective design of the study), the names and social security numbers of the patients were sent to the National Population Register in order obtain mortality and survival data.

All patients included in the study were treated by the medical staff at the Orthopedic and Traumatology Clinic. Fractures were evaluated using X-rays of the pelvis or hip. The type of osteosynthesis was decided by the treating physician. A preoperative medical evaluation was conducted by the clinic's anesthesiologist to establish operative risk and improve biological status. After surgery, all patients were included in a medical rehabilitation program under the supervision of a physical therapist.

The results obtained were overlapped with the patient database, and consequently the survival period post-fracture was obtained for the patients included in the study.

Statistical analysis was performed using IBM SPSS Version 20 software (SPSS Inc, Chicago, IL, USA). We assessed the data according to the continuous or non-parametric nature of the variable using the Fischer contingency test and the unpaired Student's t test. Continuous data were expressed as mean \pm standard error and median. In order to evaluate survival and possible influential factors, we utilized Kaplan-Meier analysis.

\section{RESULTS}

Of the 138 nonagenarian patients presenting with hip fracture, 137 were eligible for inclusion and we recruited 134 . Three patients were transferred to other hospitals at the request of the patient or family. One patient with bilateral hip fracture occurring two years after the first fracture on the opposite site was excluded from the study. The group was homogeneous by sex, age, origin, and age of disease $(p>0.05)$. There were more females than males, with a ratio of 1.7:1. (Table 1 )

There was an increasing trend in the prevalence of fractures in nonagenarian patients $(y=6.83+0.85 x)$; the prognosis for 2019 is approximately $17 \%$ prevalence. (Figure 1 )

Mean patient age was 92.53 years and median age was 92 years (range 90-103 years); 85 patients (63.5\%) were women and 49 patients (36.5\%) were men.

\begin{tabular}{|c|c|c|c|c|}
\hline Characteristics & $\begin{array}{c}\text { All patients } \\
(n=134)\end{array}$ & $\begin{array}{c}\text { Male } \\
(\mathrm{n}=49)\end{array}$ & $\begin{array}{l}\text { Female } \\
(\mathrm{n}=85)\end{array}$ & $\begin{array}{c}p \text { value } \\
\text { two-tailed probability }\end{array}$ \\
\hline Age mean SD (y) & $92.53 \quad 2.57$ & 92.612 .44 & 92.482 .65 & 0.779 \\
\hline Urban area, $\mathrm{n}(\%)$ & $91(67.9 \%)$ & $32(65.3 \%)$ & $59(69.4 \%)$ & 0.766 \\
\hline ASA score SD & 3.311 .20 & $2.92 \quad 0.93$ & 3.531 .28 & 0.004 \\
\hline \multicolumn{5}{|l|}{ Type of fracture } \\
\hline femoral neck & $48(35.8 \%)$ & $24(49.0 \%)$ & $24(28.2 \%)$ & \multirow{2}{*}{0.026} \\
\hline Intertrochanteric & $86(64.2 \%)$ & $25(51.0 \%)$ & $61(71.8 \%)$ & \\
\hline \multicolumn{5}{|l|}{ Surgery } \\
\hline internal fixation & $62(46.3 \%)$ & $22(44.9 \%)$ & $40(47.0 \%)$ & \multirow{2}{*}{0.047} \\
\hline prothesis & $32(23.9 \%)$ & $17(34.7 \%)$ & $15(17.6 \%)$ & \\
\hline
\end{tabular}

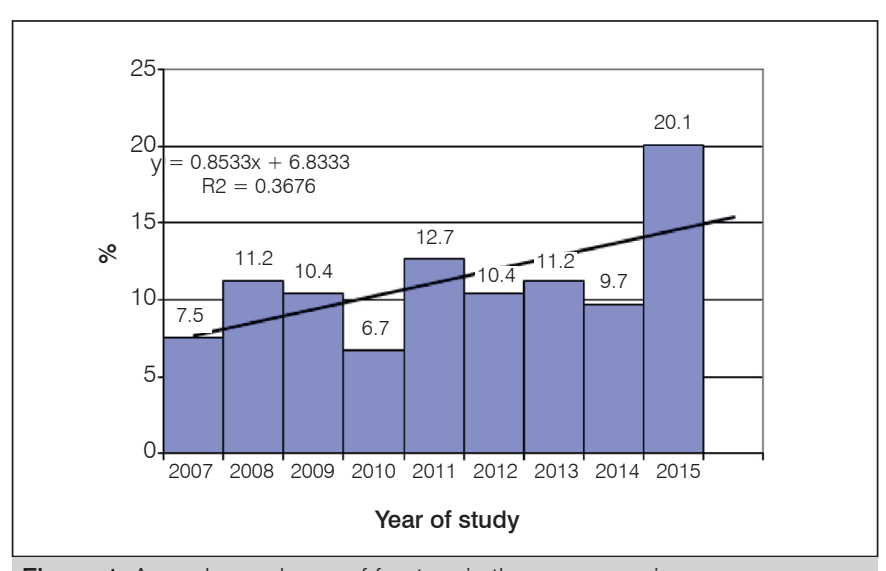

Figure 1. Annual prevalence of fracture in the nonagenarians. 
Patient sex distribution according to ASA score was bimodal in women (23.5\% ASA 2 and $36.5 \%$ ASA 3), while in males peak frequency occurred in ASA 3 (51\%). The average ASA score was significantly higher in women, 3.53 vs 2.92. ( $p=0.004)$. (Figure 2$)$ In our sample, the frequency distribution for prevalence of intertrochanteric fracture (64.2\%) was significantly higher in women than men, $71.8 \%$ vs $51 \%$. $(p=0.026)$.

In $40(29.9 \%)$ cases, a conservative non-surgical approach was chosen because of the high ASA score, the recommendation of the anesthesiologist, or in cases where the patient refused surgical treatment. Among the patients that were treated surgically, 62 (46.3\%) were treated with internal fixation and 20 (23.9\%) with arthroplasty. Arthroplasty was performed in only $34.7 \%$ of men and $17.6 \%$ of women, while internal fixation was conducted in $44.9 \%$ of the men and $47 \%$ of the women. $(p=0.047)$. (Table 1$)$

The preoperative interval varied from 0 to 15 days, with a mean of $4.34 \pm 3.33$ days; no significant differences were seen for sex $(p=0.521)$, diagnosis $(p=0.487)$, or type of surgery $(p=0.518)$. (Table 2, Figures 3 and 4)

Hospitalization ranged from 1 to 56 days, with an average of about 13 days without significant differences according to sex $(p=0.102)$ or diagnosis $(\mathrm{p}=0.537)$.

Depending on the type of surgery, patients with internal fixation were hospitalized between 2 and 56 days (15 days on average), and patients who received prosthetics were hospitalized between 5 and 27 days ( 14 days on average), especially women ( $p=0.001$ ). (Table 3, Figure 5)

The probability of survival in nonagenarian male patients with femoral neck fracture drops to about $60 \%$ in the first year, and $30 \%$ of men and $65 \%$ of women survive this type of fracture. (Figure 6)

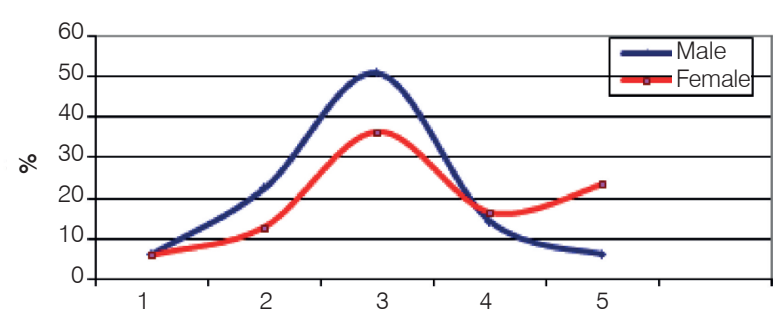

Figure 2. Distribution of ASA score according to patient sex

Table 2. Descriptive data for preoperative interval.

\begin{tabular}{|c|c|c|c|c|c|c|c|c|}
\hline & \multirow{2}{*}{$\mathrm{N}$} & \multirow{2}{*}{ Mean } & \multirow{2}{*}{$\begin{array}{c}\text { Std. } \\
\text { Deviation }\end{array}$} & \multirow{2}{*}{$\begin{array}{l}\text { Std. } \\
\text { Error }\end{array}$} & \multicolumn{2}{|c|}{$\begin{array}{l}95 \% \text { Confidence } \\
\text { Interval for Mean }\end{array}$} & \multirow{2}{*}{ Min } & \multirow{2}{*}{ Max } \\
\hline & & & & & $\begin{array}{l}\text { Lower } \\
\text { Limit }\end{array}$ & $\begin{array}{l}\text { Upper } \\
\text { Limit }\end{array}$ & & \\
\hline Total & 94 & 4.34 & 3.33 & 0.343 & 3.66 & 5.02 & 0 & 15 \\
\hline \multicolumn{9}{|c|}{ Sex } \\
\hline Female & 55 & 4.53 & 3.87 & 0.522 & 3.48 & 5.57 & 0 & 15 \\
\hline Male & 39 & 4.08 & 2.38 & 0.381 & 3.31 & 4.85 & 1 & 11 \\
\hline \multicolumn{9}{|c|}{ Diagnosis } \\
\hline $\begin{array}{l}\text { femoral neck } \\
\text { fracture }\end{array}$ & 35 & 4.03 & 2.71 & 0.457 & 3.10 & 4.96 & 1 & 13 \\
\hline $\begin{array}{l}\text { Intertrochanteric } \\
\text { fracture }\end{array}$ & 59 & 4.53 & 3.66 & 0.476 & 3.57 & 5.48 & 0 & 15 \\
\hline \multicolumn{9}{|c|}{ Surgery } \\
\hline Internal fixation & 53 & 4.19 & 3.74 & 0.513 & 3.16 & 5.22 & 0 & 15 \\
\hline $\begin{array}{c}\text { Internal fixation, } \\
3 \text { screws }\end{array}$ & 9 & 5.56 & 2.70 & 0.899 & 3.48 & 7.63 & 2 & 11 \\
\hline Prothesis & 32 & 4.25 & 2.72 & 0.482 & 3.27 & 5.23 & 2 & 13 \\
\hline
\end{tabular}

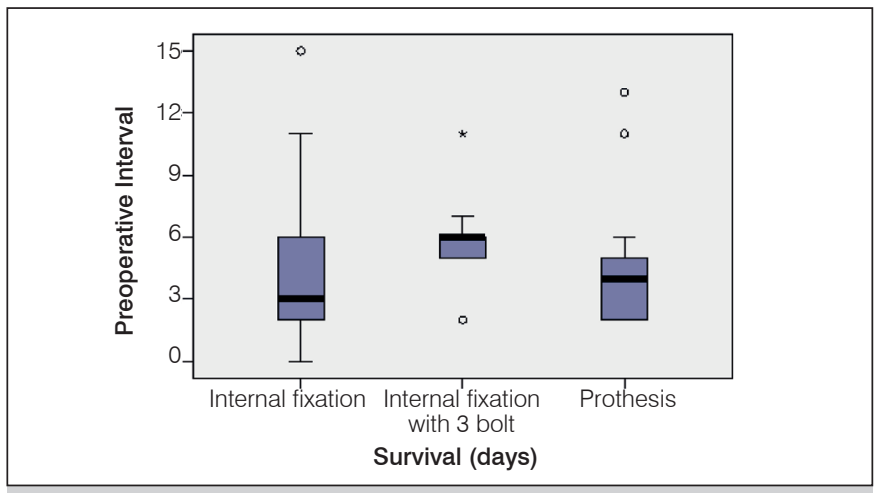

Figure 3. Average values for preoperative interval.

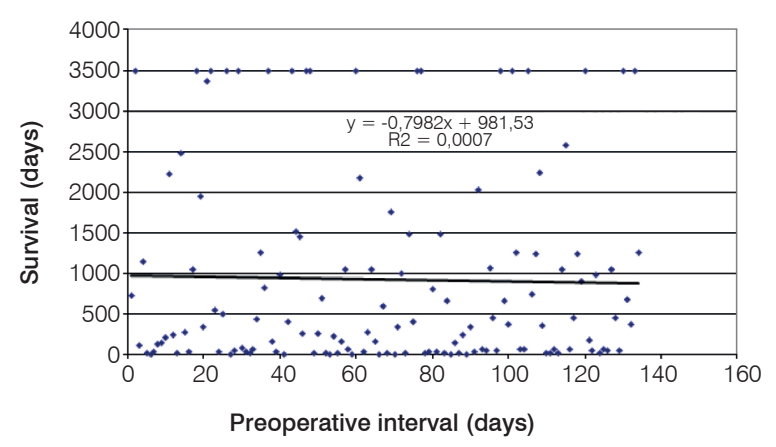

Figure 4. Correlation of survival with preoperative interval.

Table 3. Descriptive data for days of hospitalization.

\begin{tabular}{|c|c|c|c|c|c|c|c|c|}
\hline & \multirow{2}{*}{$\mathrm{N}$} & \multirow{2}{*}{ Mean } & \multirow{2}{*}{$\begin{array}{c}\text { Std. } \\
\text { Deviation }\end{array}$} & \multirow{2}{*}{$\begin{array}{l}\text { Std. } \\
\text { Error }\end{array}$} & \multicolumn{2}{|c|}{$\begin{array}{l}95 \% \text { Confidence } \\
\text { Interval for Mean } \\
\end{array}$} & \multirow{2}{*}{ Min } & \multirow{2}{*}{$\operatorname{Max}$} \\
\hline & & & & & $\begin{array}{l}\text { Lower } \\
\text { Limit }\end{array}$ & $\begin{array}{l}\text { Upper } \\
\text { Limit }\end{array}$ & & \\
\hline Total & 134 & 12.68 & 10.34 & 0.893 & 10.91 & 14.45 & 1 & 56 \\
\hline \multicolumn{9}{|c|}{ Sex } \\
\hline Female & 85 & 13.79 & 11.98 & 1.299 & 11.20 & 16.37 & 1 & 56 \\
\hline Male & 49 & 10.76 & 6.243 & 0.892 & 8.96 & 12.55 & 2 & 27 \\
\hline \multicolumn{9}{|c|}{ Diagnosis } \\
\hline $\begin{array}{l}\text { femoral neck } \\
\text { fracture }\end{array}$ & 48 & 11.94 & 6.62 & 0.955 & 10.02 & 13.86 & 2 & 27 \\
\hline $\begin{array}{l}\text { Intertrochanteric } \\
\text { fracture }\end{array}$ & 86 & 13.09 & 11.94 & 1.287 & 10.53 & 15.65 & 1 & 56 \\
\hline \multicolumn{9}{|c|}{ Surgery } \\
\hline Internal fixation & 53 & 15.08 & 13.16 & 1.808 & 11.45 & 18.70 & 2 & 56 \\
\hline $\begin{array}{l}\text { Internal fixation } \\
3 \text { screws }\end{array}$ & 9 & 15.44 & 7.96 & 2.652 & 9.33 & 21.56 & 6 & 29 \\
\hline Prothesis & 32 & 14.72 & 5.44 & 0.961 & 12.76 & 16.68 & 5 & 27 \\
\hline None & 40 & 7.25 & 7.33 & 1.160 & 4.90 & 9.60 & 1 & 30 \\
\hline
\end{tabular}

The likelihood of survival of both genres, in the first 3 years for the patients with trochanteric fracture, is reduced to $50-60 \%$, after that, is reduced to $20 \%$ in men and by $40 \%$ in women. (Figure 7 ) Patients with functional treatment had the lowest probability of survival; about $60 \%$ of cases survived the first year, with the probability of survival at 2 years at approximately $30 \%$.

Patients with internal fixation have a slightly higher probability of survival, but this drops below $40 \% 3$ years after surgery. Patients with internal fixation using 3 screws survived almost 3 years; in patients who received arthroplasty the probability of survival decreases to about $50 \%$ in the first 2 years after surgery. (Table 4, Figure 8) 


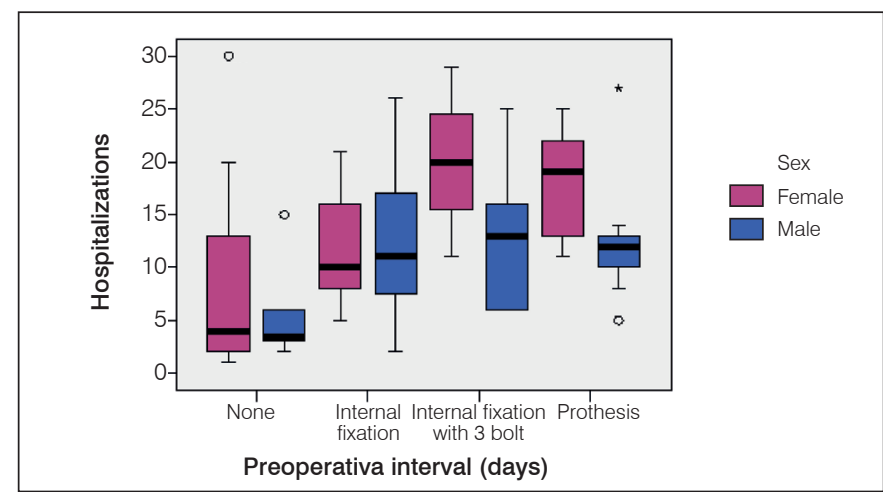

Figure 5. Average values for days of hospitalization according to surgery.

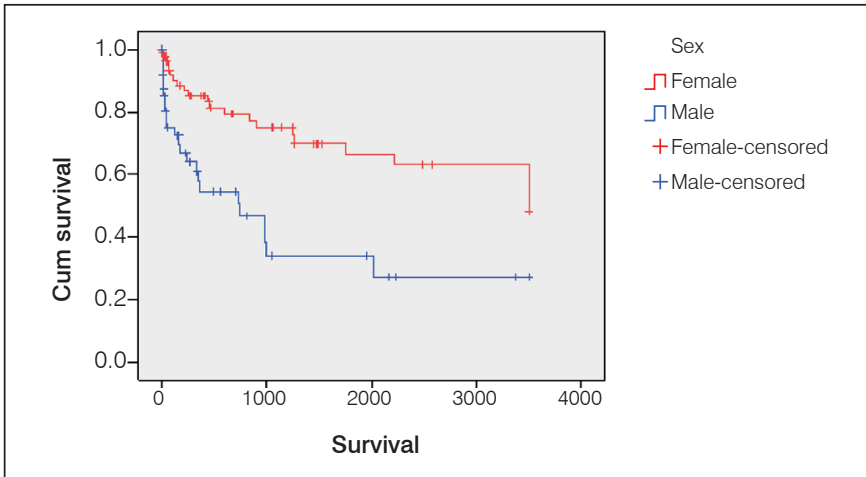

Figure 6. Survival of nonagenarian patients with femoral neck fracture.

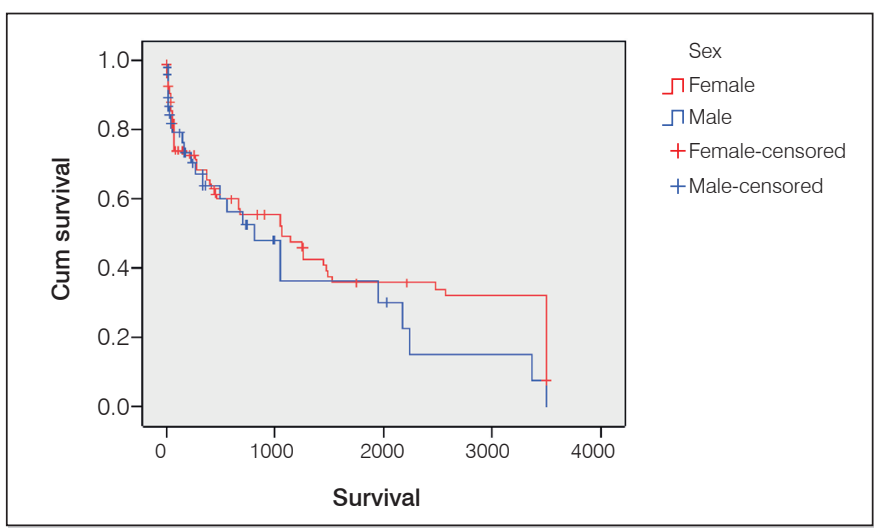

Figure 7. Survival of nonagenarian patients with trochanteric fracture.

\section{DISCUSSION}

Although this is not the first study of its kind, our investigation provides new information on postoperative survival time, the association between preoperative interval, type of treatment, and postoperative survival.

Hip fractures are a formidable pathology in elderly patients which may be associated with significant morbidity and high mortality. Despite progress in surgical techniques and postoperative care, mortality remains high: 14-30\% one year after surgery, according to recent data. ${ }^{12}$ Numerous studies have tried to identify the main factors responsible for high morbidity and mortality after a hip fracture. Most authors consider advanced age to be correlated with other factors, such as patient sex, comorbidities, ASA score, time between fracture occurrence and surgical intervention, and type of fracture.

\begin{tabular}{|c|c|c|c|c|c|c|c|}
\hline $\begin{array}{c}\text { Survival } \\
\text { Characteristics }\end{array}$ & 30 days & 90 days & 180 days & 1 year & 2 year & $\geq 3$ year & \multirow{2}{*}{$\begin{array}{l}\text { p values } \\
\text { Chi-square }\end{array}$} \\
\hline $\begin{array}{l}\text { All patients } \\
(n=134)\end{array}$ & 18.7 & 17.2 & 6.0 & 9.0 & 11.9 & 37.3 & \\
\hline Male $(n=49)$ & 32.7 & 8.2 & 10.2 & 14.3 & 8.2 & 26.5 & \multirow{2}{*}{0.001} \\
\hline Female $(n=85)$ & 10.6 & 22.4 & 3.5 & 5.9 & 14.1 & 43.5 & \\
\hline $\begin{array}{l}\text { Extracapsular } \\
\qquad(n=48)\end{array}$ & 25.0 & 12.5 & 10.4 & 12.5 & 8.3 & 31.3 & \multirow{2}{*}{0.177} \\
\hline $\begin{array}{c}\text { Intracapsular } \\
(\mathrm{n}=86)\end{array}$ & 15.1 & 19.8 & 3.5 & 7.0 & 14.0 & 40.7 & \\
\hline $\begin{array}{l}\text { Time to surgery: } \\
1-3 \text { days }(n=48)\end{array}$ & 10.4 & 14.6 & 6.3 & 8.3 & 16.7 & 43.8 & \multirow{2}{*}{0.204} \\
\hline $\begin{array}{l}\text { Time to surgery: } \\
>3 \text { days }(n=46)\end{array}$ & 23.9 & 19.6 & 2.2 & 6.5 & 4.3 & 43.5 & \\
\hline ASA 1-3 $(n=86)$ & 19.8 & 15.1 & 8.1 & 9.3 & 8.1 & 39.5 & \multirow{2}{*}{0.317} \\
\hline$A S A>3(n=48)$ & 16.7 & 20.8 & 2.1 & 8.3 & 18.8 & 33.3 & \\
\hline Operated $(n=94)$ & 17.0 & 17.0 & 4.3 & 7.4 & 10.6 & 43.6 & \multirow[b]{2}{*}{0.252} \\
\hline $\begin{array}{c}\text { Nonoperated } \\
(n=40)\end{array}$ & 22.5 & 17.5 & 10.0 & 12.5 & 15.0 & 22.5 & \\
\hline $2007-2010(n=48$ & 14.6 & 18.8 & 6.3 & 10.4 & 16.7 & 33.3 & \multirow{2}{*}{0.749} \\
\hline $2011-2015(n=86$ & 20.9 & 16.3 & 5.8 & 7.1 & 9.3 & 39.5 & \\
\hline
\end{tabular}

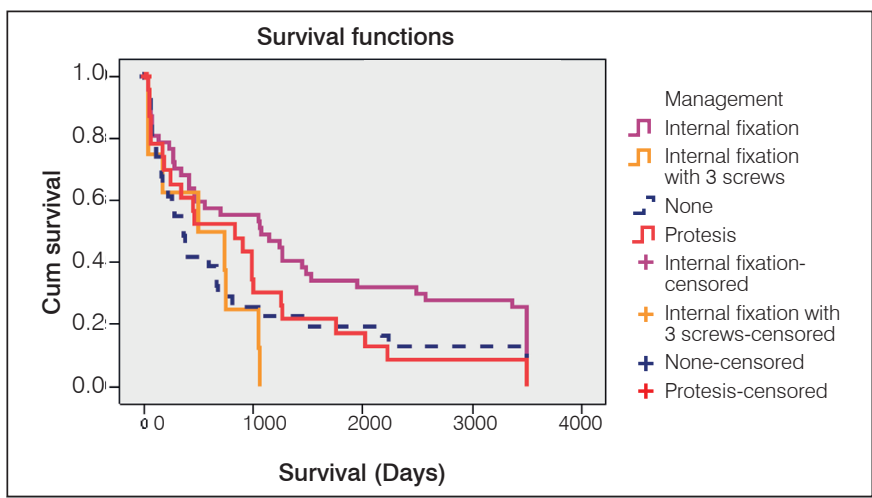

Figure 8. Survival of nonagenarian patients according to surgical intervention.

As the global population ages, an increase in the frequency of hip fractures is inevitable. Our data are in line with the rising tendency toward hip fracture in nonagenarians. ${ }^{6,13-17}$

In our study we obtained lower mortality values at one year than in the literature: $14.3-31.0 \%$ in men and $5.9-59.0 \%$ in women $(p=0.001) .^{18,19}$ The higher mortality rate in men was consistent with other previous studies. In the study by $\mathrm{Ooi}^{10}$ on 84 nonagenarian patients with hip fracture treated both surgically and non-surgically, 2 -year mortality was $49 \%$, but the study suggested that surgery significantly increases the ability to move about independently. Our study did not focus on patient mobility and independence after fracture, although we believe this is an important outcome. In our study, 2-year overall mortality was lower (11.9\%) and the group with the longest survival period also was the one that received surgical treatment with internal fixation $(14 \%, p=0.177)$.

The likelihood of survival for both sexes in the first 3 years for patients with trochanteric fracture is reduced to $50-60 \%$, and after that period is reduced to $20 \%$ in men and $40 \%$ in women.

Preoperative timeframe is another parameter which influences prognostics for elderly patients with hip fracture. Delaying the surgical intervention is necessary in the context of measures which seek to correct any possible imbalances and optimize the patient's biological status. In a 2011 study, Carretta ${ }^{3}$ found that mortality is influenced by the preoperative period, with a rate of about 3.5\% for patients operated within the first 48 hours that doubles after this period. Most 
current guides confirm that delaying surgical intervention leads to a rise in immediate mortality and mortality during hospitalization. In our group, the preoperative interval varied from 0 to 15 days with a mean of $4.34 \pm 3.33$ days, and no significant differences were seen for sex $(p=0.521)$, diagnosis $(p=0.487)$ or type of surgery $(p=0.518)$. The correlation between survival time and preoperative interval was indirect and low intensity; a short preoperative interval is associated with increased survival period in only $10.9 \%$ of nonagenarian subjects, and the results cannot be extrapolated to the general population $(r=-0.109, R 2=0.0119, p=0.297)$.

Patient sex is another parameter that must be taken into consideration when evaluating mortality. Data published in the specialized literature confirms the predisposition of females to hip fractures. In 2008 Van de Kerkhove et al. ${ }^{17}$ published a retrospective study covering a 20-year period and including 155 nonagenarian patients (83\% women, $17 \%$ men). These authors concluded that extracapsular fractures are much more frequent in women (62\%) and that this is associated with a high mortality rate. In our sample, $71.8 \%$ of women and $51 \%$ of men had an intertrochanteric fracture $(p=0.026)$. We were able to establish a correlation between type of fixation and days of hospitalization. Patients with internal fixation were hospitalized between 2 and 56 days, on average 15 days, and patients who received prosthetics stayed in the hospital between 5 and 27 days, an average of 14 days, especially women $(p=0.001)$. As for type of fracture, Kang et al. ${ }^{8}$ indicated that extracapsular fracture of the proximal femur generates higher mortality compared to intracapsular fracture. In our study, survival at 30, 90, and 180 days and 1 year post-fracture was better in extracapsular fracture patients: $25 \%, 12.5 \%, 10.4 \%$, and $12.5 \%$, as opposed to $15.1 \%, 19.8 \%, 3.5 \%$, and $7.0 \%$ in patients with intracapsular fractures.

Associated pathology influences the evolution of patients with hip fracture. An ASA score of 1-2 increases the risk of death in the first year after surgery from 0.36 to 1.33 , and for patients with an ASA score of 3-4, the risk of death goes up to 2.33. ${ }^{4}$ Our data were not conclusive on this matter, probably because the number of comorbidities often influences the type of treatment selected (conservative or surgical).
Our data, like that of other studies ${ }^{15}$ suggest that surgical treatment remains the best option, even for nonagenarian patients. Even though mortality is high, the hospitalization period long and the functional prognosis is limited, the rate of surgical complications is acceptable. The probability of survival in nonagenarian male patients with femoral neck fracture drops to about $60 \%$ in the first year, and $30 \%$ of men and $65 \%$ women can survive this type of fracture.

Patients receiving functional treatment had the lowest probability of survival, with about $60 \%$ of cases surviving the first year; the probability of survival at 2 years is approximately $30 \%$.

Patients with internal fixation have a slightly higher probability of survival, although this number drops below $40 \% 3$ years after surgery. Patients with internal fixation using 3 screws survived almost 3 years. In patients receiving arthroplasty, the probability of survival decreases to about $50 \%$ in the first 2 years after surgery. As the global population ages, an increase in the frequency of hip fractures is inevitable. The medical system will face increasingly older patients with significant associated pathologies and a predisposition to postoperative complications. Although nonagenarian patients have numerous comorbidities, surgery utilizing internal fixation seems to be superior to a conservative approach.

The main limitations of this study are the number of patients included. To detect a statistical difference in mortality, a larger study should be conducted, probably involving several thousand patients.

\section{CONCLUSION}

In conclusion, we found that mortality after hip fracture was high in nonagenarians, especially men. ASA score has a high influence in determining the type of treatment and patient survival. Although we found a low statistical significance, survival was better in patients who were surgically treated with internal fixation.

\section{ACKNOWLEDGMENTS}

The authors received no financial support for the research, authorship, and/or publication of this article.

AUTHORS' CONTRIBUTIONS: Each author made significant individual contributions to this manuscript. AO (0000-0001-9131-6104)*, PD (0000-0001-6806-3559)* and VB (0000-0002-9941-3424)* performed the surgeries, followed the patients, and collected clinical data. GTS (0000-0002-9269-3937)* performed the bibliography search, drafted the manuscript, and assessed the data from the statistical analysis. AO and AID (0000-0001-5795-4161)* reviewed the article, approved the final version of the manuscript to be submitted for publication, and contributed to the intellectual concept of the study. ${ }^{\star}$ ORCID (Open Researcher and Contributor ID).

\section{REFERENCES}

1. Beaupre LA, Jones CA, Saunders LD, Johnston DW, Buckingham J, Majumdar SR. Best practices for elderly hip fracture patients. A systematic overview of the evidence. J Gen Intern Med. 2005;20(11):1019-25.

2. Silveira VAL, Medeiros MMC, Coelho-Filho JM, Mota RS, Noleto JCS, Costa FS, et al. Incidência de fratura do quadril em área urbana do Nordeste brasileiro. Cad Saúde Pública. 2005:21(3):907-12.

3. Carretta E, Bochicchio V, Rucci P, Fabbri G, Laus M, Fantini MP. Hip fracture: effectiveness of early surgery to prevent 30-day mortality. Int Orthop. 2011;35(3):419-24

4. Holt G, Macdonald D, Fraser M, Reece AT. Outcome after surgery for fracture of the hip in patients aged over 95 years. J Bone Joint Surg Br. 2006;88(8):1060-4.

5. Patil S, Parcells B, Balsted A, Chamberlain RS. Surgical Outcome following hip fracture in patients $>100$ years old: will they ever walk again? Surg Sci. 2012;3:554-9.

6. Formiga F, Lopez-Soto A, Sacanella E, Coscojuela A, Suso S, Pujol R. Mortality and morbidity in nonagenarian patients following hip fracture surgery. Gerontology. 2003:49(1):41-5.

7. Parker MJ, Handoll HH, Bhargara A. Conservative versus operative treatment for hip fractures. Cochrane Database Syst Rev. 2000;(4):CD000337. Review. Update in: Cochrane Database Syst Rev. 2008;(3):CD000337.

8. Kang BJ, Lee YK, Lee KW, Won SH, Ha YC, Koo KH. Mortality after hip fractures in nonagenarians. J Bone Metab. 2012;19(2):83-6.

9. Aharonoff GB, Barsky A, Hiebert R, Zuckerman JD, Koval KJ. Predictors of discharge to a skilled nursing facility following hip fracture surgery in New York State. Gerontology. 2004;50(5):298-302.

10. Hindmarsh DM, Hayen A, Finch CF, Close JC. Relative survival after hospitalisation for hip fracture in older people in New South Wales, Australia.Osteoporos Int 2009;20(2):221-9.

11. Ma RS, Gu GS, Huang X, Zhu D, Zhang Y, Li M, et al. Postoperative mortality and morbidity in octogenarians and nonagenarians with hip fracture: an analysis of perioperative risk factors. Chin J Traumatol. 2011;14(6):323-8.

12. Magaziner J, Simonsick EM, Kashner TM, Hebel JR, Kenzora JE. Survival experience of aged hip fracture patients. Am J Public Health. 1989;79(3):274-8.

13. Cree M, Soskolne CL, Belseck E, Hornig J, McElhaney JE, Brant R, et al. Mortality and institutionalization following hip fracture. J Am Geriatr Soc. 2000;48(3):283-8.

14. Formiga F, Lopez-Soto A, Duaso E, Chivite D, Ruiz D, Perez-Castejon JM, et al Characteristics of falls producing hip fractures in nonagenarians. J Nutr Health Aging. 2008;12(9):664-7.

15. Hagino T, Ochiai S, Wako M, Sato E, Maekawa S, Hamada Y. Comparison of the prognosis among different age groups in elderly patients with hip fracture. Indian J Orthop. 2008;42(1):29-32.

16. Kanis JA, Oden A, Johnell O, De Laet C, Jonsson B, Oglesby AK. The components of excess mortality after hip fracture. Bone. 2003;32(5):468-73.

17. van de Kerkhove MP. Antheunis PS, Luitse JS, Goslings JC. Hip fractures in nonagenarians: perioperative mortality and survival. Injury. 2008;39(2):244-8.

18. Dubljanin-Raspopovi E, Markovi -Deni L, Marinkovi J, Nedeljkovi U, Bumba irevi M. Does early functional outcome predict 1-year mortality in elderly patients with hip fracture? Clin Orthop Relat Res. 2013;471(8):2703-10.

19. Lee DJ, Elfar JC. Timing of hip fracture surgery in the elderly. Geriatr Orthop Surg Rehabil. 2014;5(3):138-40. 
In the article entitled "SURVIVAL OF NONAGENARIAN PATIENTS WITH HIP FRACTURES: A COHORT STUDY" authored by Alexa Ovidiu; Gheorghevici Teodor Stefan; Popescu Dragos; Veliceasa Bogdan; Alexa loana Dana, published in Revista Acta Ortopédica Brasileira (ACTA) vol. 25 n 4, 2017, page 132, DOI: http://dx.doi.org/10.1590/1413-785220172504167561, by request of the authors.

The text reading: Citation: Ovidiu A, Stefan GT, Dragos P, Bogdan V, Dana Al. Survival of nonagenarian patients with hip fractures: a cohort study. Acta Ortop Bras. [online]. 2017;25(4):132-6. Available from URL: http://www.scielo.br/aob.

Is replaced with: Citation: Alexa O, Gheorghevici TS, Popescu D, Veliceasa B, Alexa ID. Survival of nonagenarian patients with hip fractures: a cohort study. Acta Ortop Bras. [online]. 2017;25(4):132-6. Available from URL: http://www.scielo.br/aob. 